\title{
Thermodynamic study to evaluate the selectivity behaviour of nuclear grade resin Indion-223 towards some univalent ions
}

\author{
Pravin U. Singare ${ }^{1, *}$, Akmal L. Khan Mohammed ${ }^{1}$, N. N. Dixit ${ }^{2}$ \\ ${ }^{1}$ Department of Chemistry, Bhavan's College, Munshi Nagar, Andheri (West), \\ Mumbai - 400058, India \\ ${ }^{2}$ Department of Chemistry, Maharashtra College, Jahangir Boman Behram Marg, Nagpada, \\ Mumbai - 400008, India \\ *E-mail address: pravinsingare@gmail.com
}

\begin{abstract}
The present paper deals with the application of thermodynamic concept in understanding the preferential selectivity of nuclear grade anion exchange resin Indion-223 in $\mathrm{H}^{+}$form towards $\mathrm{Na}^{+}$and $\mathrm{K}^{+}$ions in the solution. In the study it was observed that the equilibrium constants $K$ values for $\mathrm{H}^{+} / \mathrm{Na}^{+}$ and $\mathrm{H}^{+} / \mathrm{K}^{+}$uni-univalet ion exchange reactions increases from 0.01389 to 0.01855 and from 0.01710 to 0.02374 respectively as the temperature increases from $35.0{ }^{\circ} \mathrm{C}$ to $45.0^{\circ} \mathrm{C}$. The increase in $K$ values with rise in temperature suggests endothermic ion exchange reactions having the enthalpy change values of 25.55 and $22.72 \mathrm{~kJ} / \mathrm{mol}$ respectively. Based on difference in $K$ values and enthalpy values for the two uni-univalent ion exchange reactions, the preferential selectivity of the resin for the univalent ions in the solution was predicted. From the results of present study, it appears that the experimental technique used here can be applied further to understand the ionic selectivity of different industrial grade ion exchange resins. It is expected that such studies will provide valuable information in order to decide about the selection of those resins for efficient separation of various ionic species present in the industrial waste water effluents.
\end{abstract}

Keywords: uni-univalent ion exchange reactions; ionic selectivity; nuclear grade resins; cation exchangers; enthalpy change; equilibrium constant; Indion-223

\section{INTRODUCTION}

A wide variety of technical methods is available for processing liquid radioactive waste generated in the nuclear power industry and during various nuclear applications. One of the most common methods for treatment of liquid radioactive waste is the use of ion exchange, which is a well developed technique that has been employed for many years in both the nuclear industry and in other industries [1]. In spite of its advanced stage of development, various aspects of ion exchange technology are being studied to improve its efficiency and economy in its application to radioactive waste management [2]. Highly specific nuclear grade ion exchange resins are readily available for radionuclides which are common in the nuclear industry [3-7]. Efforts to develop new organic ion exchangers for their specific applications in nuclear industries are continuing and various aspects of ion exchange technologies have been continuously studied to improve the efficiency and economy of their 
application in various technological applications [8-34]. However, since the selection of the appropriate ion-exchange material depends on the needs of the system, it is expected that the data obtained from the actual experimental trials will prove to be more helpful. Hence there is a need to evaluate systematically the performance of such organic ion exchange resins under various operational conditions.

Considerable work was done by previous researchers to study the properties of the ion exchange resins, to generate thermodynamic data related to various uni-univalent and heterovalent ion exchange systems [35-41]. Recently theories explaining ion exchange equilibrium between the resin phase and solution was also developed [42]. A number of researchers carried out equilibrium studies, extending over a wide range of composition of solution and resin phase [43-73]. Attempts were also made to study the temperature effect on anion exchange systems [58-73] for computing the thermodynamic equilibrium constants. However very little work was carried out to study the equilibrium of cation exchange systems [43-57]. Therefore, in the present investigation, thermodynamics study of uni-univalent ion exchange reactions was made to predict the selectivity behaviour of strongly acidic gel type nuclear grade cation exchange resin Indion-223 towards some univalent ions in the solution.

\section{MATERIALS AND METHODS}

Glasswares: All apparatus used in the study were made up of Pyrex or Coming glass. Microburette of $0.02 \mathrm{~mL}$ accuracy was used for the entire experimental work.

Analytical balance: For weighing the sample above $25 \mathrm{mg}$, analytical balance of $0.1 \mathrm{mg}$ sensitivity was used. Metler balance was used for weighing the samples less than $25 \mathrm{mg}$.

Potentiometer: Digital potentiometer of Equiptronics make having saturated calomel electrode as a reference electrode and platinum electrode in contact with quinhydrone as an indicator electrode was used in the experimental work.

All Chemicals used were of analytical reagent (AR) grade. Distilled deionised water was used throughout the experiments for solution preparation.

Ion exchange Resin: The ion exchange resin Indion 223 as supplied by the manufacturer (Ion Exchange India Limited, Mumbai) was a strongly acidic gel type nuclear grade anion exchange resin in $\mathrm{H}^{+}$form having styrene divinyl benzene cross-linking. The resin was having $-\mathrm{SO}_{3}{ }^{-}$functional group, having moisture content of $50-55 \%$. The operational $\mathrm{pH}$ range was 0 14 and maximum operating temperature was $120^{\circ} \mathrm{C}$.

The soluble non-polymerized organic impurities of the resin were removed by repeated Soxhlet extraction using distilled deionised water and occasionally with methanol. In order to ensure complete conversion of resins in $\mathrm{H}^{+}$form, the resins were conditioned with $0.1 \mathrm{~N} \mathrm{HCl}$ in a conditioning column. The resins were further washed with distilled deionised water until the washings were free from $\mathrm{H}^{+}$ions. The resins in $\mathrm{H}^{+}$form were air dried over $\mathrm{P}_{2} \mathrm{O}_{5}$ and used for further studies.

The ion exchange resins in $\mathrm{H}^{+}$form were equilibrated separately with $\mathrm{Na}^{+}$and $\mathrm{K}^{+}$ univalent ion solution of different but known concentrations in the temperature range of 35.0$45.0{ }^{\circ} \mathrm{C}$ for $3 \mathrm{~h}$. After $3 \mathrm{~h}$ the concentration of $\mathrm{H}^{+}$ions exchanged in the solution was determined experimentally by potentiometric titration against standard $0.1 \mathrm{~N} \mathrm{NaOH}$ solution. From the knowledge of amount of $\mathrm{H}^{+}$ions exchanged in the solution and $\mathrm{Na}^{+}$and $\mathrm{K}^{+}$ions exchanged on the resin; equilibrium constant $(K)$ for the reactions 


$$
\begin{aligned}
& \mathrm{R}-\mathrm{H}+\mathrm{Na}^{+}{ }_{\text {(aq.) }} \rightleftharpoons \mathrm{R}-\mathrm{Na}+\mathrm{H}^{+}{ }_{\text {(aq.) }} \\
& \mathrm{R}-\mathrm{H}+\mathrm{K}^{+}{ }_{\text {(aq.) }} \rightleftharpoons \mathrm{R}-\mathrm{K}+\mathrm{H}^{+}{ }_{\text {(aq.) }}
\end{aligned}
$$

were calculated. From the $K$ values obtained at different temperatures, the enthalpy change values of the above uni-univalent ion exchange reactions were calculated.

\section{RESULTS AND DISCUSSION}

The equilibrium constants $(K)$ for reactions 1 and 2 were calculated by the equation

$$
K=\frac{\mathrm{C}_{\mathrm{R}-\mathrm{X}} \cdot \mathrm{C}_{\mathrm{H}^{+}}}{\left(A-\mathrm{C}_{\mathrm{R}-\mathrm{X}}\right) \cdot \mathrm{C}_{\mathrm{X}^{+}}}
$$

here, $\mathrm{R}$ represent the resin phase; $A$ is the ion exchange capacity of the resin; $\mathrm{X}$ represents $\mathrm{Na}^{+}$ or $\mathrm{K}^{+}$ions. For different concentrations of $\mathrm{X}^{+}$ions in solution at a given temperature, $K$ values were calculated and an average of $K$ for this set of experiment was obtained (Tables 1 and 2).

Table 1. Equilibrium constant for the ion exchange reaction $\mathrm{R}-\mathrm{H}+\mathrm{Na}^{+}$(aq.) $\rightleftharpoons \mathrm{R}-\mathrm{Na}+\mathrm{H}^{+}$(aq.) using Indion-223 resin Amount of the ion exchange resin in $\mathrm{H}^{+}$form $=0.500 \mathrm{~g}$, Ion exchange capacity $=2.91$, Temperature $=45.0^{\circ} \mathrm{C}$.

\begin{tabular}{|c|c|c|c|c|c|c|}
\hline System & $\begin{array}{c}\text { Initial } \\
\text { concentration } \\
\text { of } \mathrm{Na}^{+} \\
\text {ion (M) }\end{array}$ & $\begin{array}{c}\text { Final } \\
\text { concentration } \\
\text { of } \mathrm{Na}^{+} \\
\text {ions }(\mathrm{M}) \\
\mathrm{C}_{\mathrm{Na}+}\end{array}$ & $\begin{array}{c}\text { Change } \\
\text { in } \mathrm{Na}^{+} \\
\text {ion } \\
\text { concentration }\end{array}$ & $\begin{array}{c}\text { Concentration } \\
\text { of } \mathrm{H}^{+} \text {ions } \\
\text { exchanged } \\
(\mathrm{M}) \\
\mathrm{C}_{\mathrm{H}+}\end{array}$ & $\begin{array}{c}\text { Amount of } \\
\mathrm{Na}^{+} \text {ions } \\
\text { exchanged } \\
\text { on the resin } \\
\text { meq./0.5 g } \\
\mathrm{C}_{\mathrm{RNa}}\end{array}$ & $\begin{array}{c}\text { Equilibrium } \\
\text { constant } \\
\mathrm{K} \mathrm{x} 10^{-2}\end{array}$ \\
\hline 1 & 0.0100 & 0.0066 & 0.0034 & 0.0034 & 0.1715 & 3.267 \\
\hline 2 & 0.0500 & 0.0442 & 0.0058 & 0.0058 & 0.2934 & 1.480 \\
\hline 3 & 0.1000 & 0.0937 & 0.0063 & 0.0063 & 0.3182 & 0.820 \\
\hline \multicolumn{7}{|c|}{ Average $\mathrm{K}$} \\
\hline
\end{tabular}

Similar $K$ values were calculated for the reactions 1 and 2 performed at different temperatures (Table 3 ). From the slope of the graph of $\log K$ against $1 / \mathrm{T}$ (in Kelvin) the enthalpy change values of the ion exchange reactions 1 and 2 were calculated (Figure 1). 


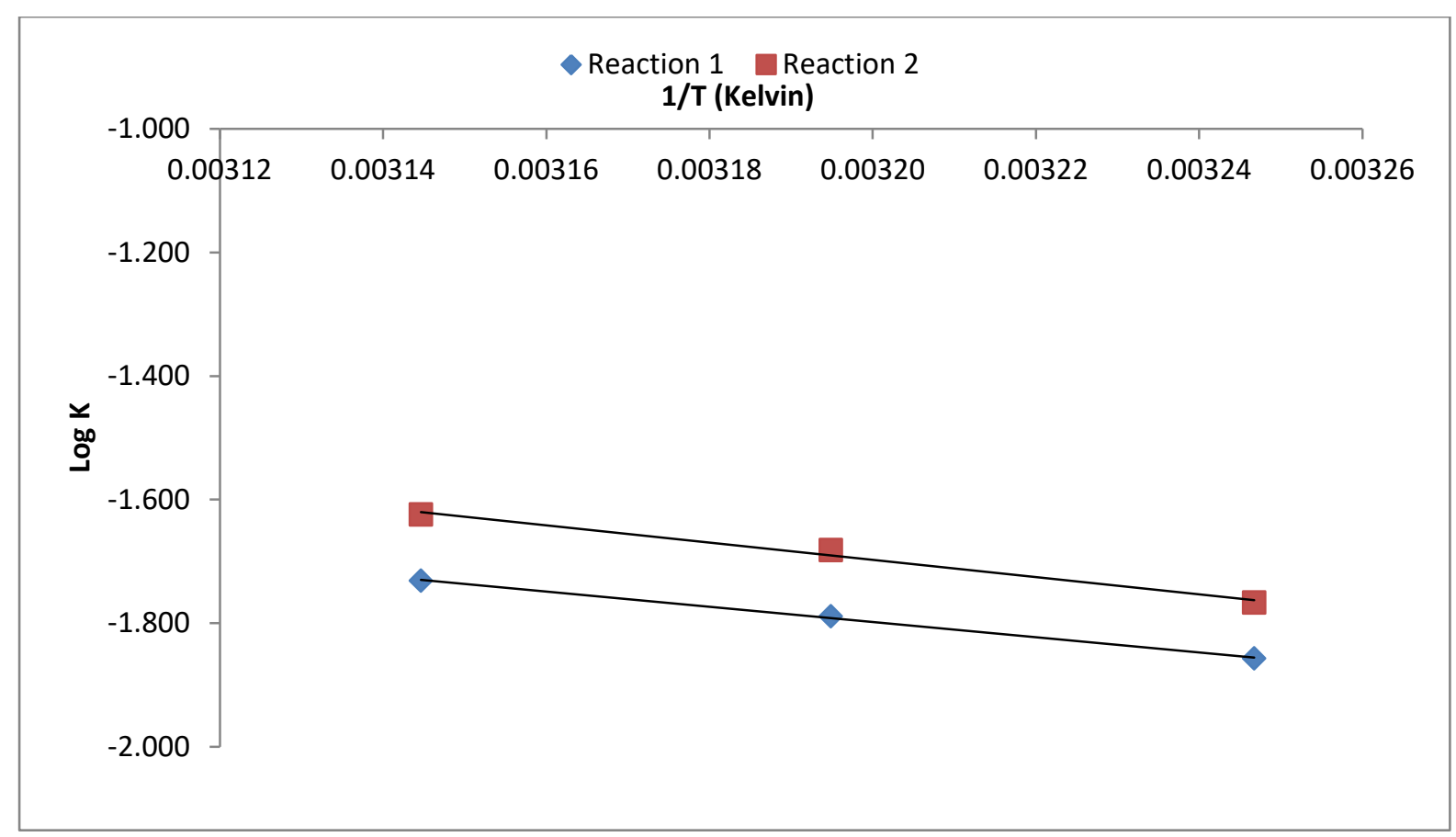

Figure 1. Variation of equilibrium constant with temperature for uni-univalent ion exchange reactions performed by using Indion-223 resins.

The equilibrium constant $K$ values for the above reactions were found to increase with rise in temperature indicating endothermic ion exchange reactions having the enthalpy change values of 25.55 and $22.72 \mathrm{~kJ} / \mathrm{mol}$ respectively (Table 3 ).

The low enthalpy and high equilibrium constant values for $\mathrm{H}^{+} / \mathrm{K}^{+}$as compared to that obtained for $\mathrm{H}^{+} / \mathrm{Na}^{+}$exchange indicates preferential selectivity of the Indion-223 resins in $\mathrm{H}^{+}$ form towards $\mathrm{K}^{+}$ions than that towards $\mathrm{Na}^{+}$ions when both of them are present in the same solution.

Table 2. Equilibrium constant for the ion exchange reaction

$\mathrm{R}-\mathrm{H}+\mathrm{K}^{+}{ }_{\text {(aq.) }} \rightleftharpoons \mathrm{R}-\mathrm{K}+\mathrm{H}^{+}$(aq.) using Indion-223 resin Amount of the ion exchange resin in $\mathrm{H}^{+}$form $=0.500 \mathrm{~g}$, Ion exchange capacity $=2.91$, Temperature $=45.0^{\circ} \mathrm{C}$.

\begin{tabular}{|c|c|c|c|c|c|c|}
\hline System & $\begin{array}{c}\text { Initial } \\
\text { concentration } \\
\text { of } \mathrm{K}^{+} \\
\text {ion (M) }\end{array}$ & $\begin{array}{c}\text { Final } \\
\text { concentration } \\
\text { of } \mathrm{K}^{+} \\
\text {ions }(\mathrm{M}) \\
\mathrm{C}_{\mathrm{K}+}\end{array}$ & $\begin{array}{c}\text { Change } \\
\text { in } \mathrm{K}^{+} \\
\text {ion } \\
\text { concentration }\end{array}$ & $\begin{array}{c}\text { Concentration } \\
\text { of } \mathrm{H}^{+} \text {ions } \\
\text { exchanged } \\
(\mathrm{M}) \\
\mathrm{C}_{\mathrm{H}}\end{array}$ & $\begin{array}{c}\text { Amount of } \mathrm{K}^{+} \\
\text {ions } \\
\text { exchanged on } \\
\text { the resin } \\
\text { meq./0.5 g } \\
\mathrm{C}_{\mathrm{RK}}\end{array}$ & $\begin{array}{c}\text { Equilibri } \\
\text { um } \\
\text { constant } \\
\mathrm{K} \mathrm{x} 10^{-2}\end{array}$ \\
\hline 1 & 0.0100 & 0.0061 & 0.0039 & 0.0039 & 0.1977 & 4.707 \\
\hline 2 & 0.0500 & 0.0439 & 0.0060 & 0.0060 & 0.3081 & 1.646 \\
\hline 3 & 0.1000 & 0.0939 & 0.0061 & 0.0061 & 0.3072 & 0.769 \\
\hline \multicolumn{7}{|c|}{ Average $\mathrm{K}$} \\
\hline
\end{tabular}


Table 3. Thermodynamics of ion exchange reactions using Indion-223 resin.

\begin{tabular}{|c|c|c|c|c|c|c|}
\hline Reactions & \multicolumn{3}{|c|}{1} & \multicolumn{3}{c|}{2} \\
\hline Temperature $\left({ }^{\circ} \mathrm{C}\right)$ & 35.0 & 40.0 & 45.0 & 35.0 & 40.0 & 45.0 \\
\hline Equilibrium Constant $(\boldsymbol{K})$ & 0.01389 & 0.01624 & 0.01855 & 0.01710 & 0.02080 & 0.02374 \\
\hline $\begin{array}{c}\text { Enthalpy Change } \Delta \mathrm{H}^{\mathrm{o}} \\
\left(\mathrm{kJ} \cdot \mathrm{mol}^{-1}\right)\end{array}$ & \multicolumn{3}{|c|}{25.55} & \multicolumn{3}{c|}{22.72} \\
\hline
\end{tabular}

\section{CONCLUSION}

From the results of present study, it appears that the experimental technique used here can be applied further to understand the ionic selectivity of different industrial grade ion exchange resins. It is expected that such studies will provide valuable information in order to decide about the selection of those resins for efficient separation of various ionic species present in the industrial waste water effluents.

\section{References}

[1] Application of Ion Exchange Processes For the Treatment of Radioactive Waste and Management of Spent Ion Exchangers, Technical Reports Series No. 408, International Atomic Energy Agency, Vienna, (2002).

[2] A. Hussain, D. Al-Othmany, Advances in Physics Theories and Applications, 15, 79-89 (2013).

[3] S.K. Samanta, M. Ramaswamy, B.M. Misra, B.M., Sep. Sci. Technol., 27, 255-267 (1992).

[4] S.K. Samanta, M. Ramaswamy, P. Sen, N. Varadarajan, R.K. Singh, Removal of radiocesium from alkaline IL waste, Natl Symp. On Management of Radioactive and Toxic Wastes (SMART- 93), Kalpakkam, 1993, Bhabha Atomic Research Centre, Bombay 56- 58(1993).

[5] S.K. Samanta, T.K. Theyyunni, B.M. Misra, J. Nucl. Sci. Technol., 32, 425-429 (1995).

[6] Y. Kulkarni, S.K. Samanta, S.Y. Bakre, K. Raj, M.S. Kumra, Process for treatment of intermediate level radioactive waste based on radionuclide separation, Waste Management'96 (Proc. Int. Symp Tucson, AZ, 1996), Arizona Board of Regents,Phoenix, AZ (1996) (CD-ROM).

[7] L.A. Bray, R.J. Elovich, K.J. Carson, Cesium Recovery using Savannah River Laboratory Resorcinol-formaldehyde Ion Exchange Resin, Rep. PNL-7273, Pacific Northwest Lab., Richland, WA (1990).

[8] P. Barbaro, F. Liguori, Chem. Rev., 109 (2), 515-529 (2009).

[9] R. Kumaresan, K.N. Sabharwal, T.G. Srinivasan, P.R. Vasudeva Rao, G. Dhekane, Solvent Extraction and Ion Exchange, 24(4), 589-602 (2006). 
[10] P.U. Singare, Journal of Analytical Science and Technology, 5, 30 (2014).

[11] P.U. Singare, Kerntechnik, 79(1), 51-57 (2014).

[12] P.U. Singare, Diffusion Fundamentals Online Journal, 19(4), 1-21 (2013).

[13] P.U. Singare, Journal of Radioanalytical and Nuclear Chemistry, 299: 591-598 (2014).

[14] P.U. Singare, International Journal of Nuclear Energy Science and Technology, 8(2), 157-170 (2014).

[15] P.U. Singare, Nuclear Engineering and Technology, 46(1), 93-100 (2014).

[16] P.U. Singare, Colloid Journal, 76(2), 193-201 (2014).

[17] P.U. Singare, Journal of Nuclear Energy Science \& Power Generation Technology, 2(2), 1-6 (2013).

[18] P.U. Singare, International Letters of Chemistry, Physics and Astronomy 13 (2013) 3749.

[19] P.U. Singare, International Letters of Chemistry, Physics and Astronomy 13 (2013) 5062.

[20] P.U. Singare, International Letters of Chemistry, Physics and Astronomy 13 (2013) 6376.

[21] P.U. Singare, International Letters of Chemistry, Physics and Astronomy 13 (2013) 77 89.

[22] P.U. Singare, International Letters of Chemistry, Physics and Astronomy 12 (2013) 113.

[23] P.U. Singare, International Letters of Chemistry, Physics and Astronomy 12 (2013) 1427.

[24] P.U. Singare, International Letters of Chemistry, Physics and Astronomy 6 (2013) 1-5.

[25] P.U. Singare, R.S. Lokhande, Ionics, 18(4), 351-357 (2012).

[26] P.U. Singare, Journal of Modern Chemistry \& Chemical Technology, 5(1), 34-44 (2014).

[27] P.U. Singare, Journal of Nuclear Engineering \& Technology, 4(1), 13-24 (2014).

[28] P.U. Singare, Journal of Nuclear Engineering \& Technology,4(1), 1-12 (2014).

[29] P.U. Singare, Journal of Nuclear Engineering \& Technology, 3(3), 1-11 (2013).

[30] P.U. Singare, Journal of Nuclear Engineering \&Technology, 3(2), 14-24 (2013).

[31] R. N. Singru, Archives of Applied Science Research, 3(5): 309-325 (2011).

[32] R. N. Singru, ISRN Thermodynamics, 2012 (2012), Article ID 323916, 8 pages doi: $10.5402 / 2012 / 323916$.

[33] P.U. Singare, R.S. Lokhande, R.S.Madyal, Open Journal of Physical Chemistry, 1(2), 45-54 (2011).

[34] P.U. Singare, R.S. Lokhande, R.S.Madyal, Rus. J. Gen .Chem., 80(3), 527-532 (2010).

[35] N.N. Andreev, Yu.I. Kuznetsov, Russ. J. Phys. Chem., 64, 1537 (1990).

[36] A. Bhargava, C. Janardanan, Indian Journal Chemistry, 36A, 624 (1997). 
[37] D. Muraviev, A. Gonzalo, M. Valiente, Anal. Chem., 67, 3028 (1995).

[38] G.E. Boyd, F. Vaslow, S. Lindenbaum, J. Phys. Chem., 71, 2214 (1967).

[39] J.F. Duncan, Aus. J. Chem. Soc., 8, 1 (1955).

[40] G.E. Boyd, F. Vaslow, S. Lindenbaum, J. Phys. Chem., 68, 590 (1964).

[41] A. Schwarz, G.E. Boyd, J. Phys. Chem., 69, 4268 (1965).

[42] N.I. Gamayunov, Russ. J. Phys. Chem., 64, 1787 (1990).

[43] G.E. Boyd, G.E. Myers, J. Phys. Chem., 60, 521 (1956).

[44] O.D. Bonner, J. Phys. Chem., 59, 719 (1955).

[45] O.D. Bonner, J. Phys. Chem., 58, 318 (1954).

[46] S. Lindenbaum, C.F. Jumper, G.E. Boyd, J. Phys. Chem., 63, 1924 (1959).

[47] K.A. Kraus, R.J. Raridon, J. Phys. Chem., 63, 1901 (1959).

[48] O.D. Bonner, W.H. Payne, J. Phys. Chem., 58,183 (1954).

[49] W.J. Argersinger, A.W. Davidson, J. Phys. Chem., 56, 92 (1952).

[50] O.D. Bonner, R.R. Pruett, J. Phys. Chem., 63, 1420 (1959).

[51] O.D. Bonner, F.L.Livingston, J. Phys. Chem., 60, 530 (1956).

[52] O.D. Bonner, L.L. Smith, J. Phys. Chem., 61, 326 (1957).

[53] O.D. Bonner, C.F. Jumper, O.C. Rogers, J. Phys. Chem., 62, 250 (1958).

[54] O.D. Bonner, L.L. Smith, J. Phys. Chem., 61, 1614 (1957).

[55] J. Kielland, J.Soc. Chem. Ind., 54, 232 (1935).

[56] A.P. Vanselow, J. Am. Chem. Soc., 54, 1307 (1932).

[57] G.L. Gaines (Jr.), H.C.Thomas, J. Chem. Phys., 21, 714 (1953).

[58] K.A. Kraus, R.J. Raridon, D.L. Holcomb, Chromatogr. J., 3,178 (1960).

[59] R.S. Lokhande, P.U. Singare, A.B. Patil, Russ. J. Phys. Chem. A, 81, 2059 (2007).

[60] P.U. Singare, R.S. Lokhande, T.S. Prabhavalkar, Bull. Chem. Soc. Ethiop., 22, 415 (2008).

[61] R.S. Lokhande, P. U. Singare, Journal of Indian Council Chemists, 24, 73 (2007).

[62] R.S. Lokhande, P.U. Singare, A.R. Kolte, Bull. Chem. Soc. Ethiop., 22,107 (2008).

[63] K.G.Heumann, K. Baier, Chromatographia, 15, 701 (1982).

[64] O.D. Bonner, G. Dickel, H. Brummer, Z. Physik. Chem., 25, 81 (1960).

[65] G.L. Starobinet, V.S. Soldatov, A.A. Krylova, Russ. J. Phys. Chem., 41, 194 (1967).

[66] P.U. Singare, A.N. Patange, International Letters of Chemistry, Physics and Astronomy 11(1) (2014) 67-73.

[67] P.U. Singare, A.N. Patange, International Letters of Chemistry, Physics and Astronomy 11(1) (2014) 44-50.

[68] P. U. Singare, A. N. Patange, International Letters of Chemistry, Physics and Astronomy 6 (2014) 8-15. 
[69] P. U. Singare, A. N. Patange, International Letters of Chemistry, Physics and Astronomy $6(2014)$ 1-7.

[70] Pravin U. Singare, Akmal L. Khan Mohammed, N. N. Dixit, International Letters of Chemistry, Physics and Astronomy 14(2) (2014) 127-135.

[71] Pravin U. Singare, Akmal L. Khan Mohammed, N. N. Dixit, International Letters of Chemistry, Physics and Astronomy 14(2) (2014) 190-198.

[72] Pravin U. Singare, Akmal L. Khan Mohammed, N. N. Dixit, International Letters of Chemistry, Physics and Astronomy 14(2) (2014) 199-207.

[73] Pravin U. Singare, Akmal L. Khan Mohammed, N. N. Dixit, International Letters of Chemistry, Physics and Astronomy 14(2) (2014) 231-239. 